\title{
Oribatid mites (Acari, Oribatida) of steppe vegetation on cape Tarhankut in Crimea (Ukraine)
}

\author{
STANISŁAW SENICZAK ${ }^{1}$, SŁAWOMIR KACZMAREK ${ }^{2}$ and ANNA SENICZAK ${ }^{1}$ \\ ${ }^{1}$ Department of Ecology, University of Technology and Life Sciences, Kordeckiego 20, \\ 85-225 Bydgoszcz, ${ }^{2}$ Department of Zoology, Kazimierz Wielki University, Ossolińskich Av. 12, \\ Bydgoszcz; stseni@atr.bydgoszcz.pl
}

(Received on 3 January 2008; Accepted on 19 October 2009)

\begin{abstract}
Oribatid mites were investigated in patches of steppe vegetation, dominated by esparto (Stipa sp.), other grasses, Artemisia caucasica, Sedum sp., mosses, or lichens, on cape Tarhankut in Crimea (Mediterranean climate). These mites were quite abundant and rich in species there, probably thanks to the fresh sea breeze and geographic expansion of species from the Mediterranean region, Central Asia, and Europe. They achieved the highest density in patches of steppe grasses other than esparto, but most species occurred in sedum patches. The most abundant was Tectocepheus velatus, especially in patches of steppe grasses other than esparto, and relatively abundant were Scutovertex sp. 1, Jacotella neonominata and Scheloribates laevigatus. In populations of these species the adults usually dominated, but their age structure greatly depended on vegetation type.
\end{abstract}

Keywords: Crimea, Tarhankut, steppe vegetation, Oribatida, mites, population, juvenile stages

\section{INTRODUCTION}

The Crimea Peninsula lies in south Ukraine, on the Black Sea, and has the same latitude as Venice. Therefore its climate is Mediterranean, with a warm (or hot) dry season, which lasts from May to October, and a cool season with some precipitation, which lasts from November to April. Generally, precipitation is low here, but the fresh sea breeze slightly lowers the costal temperature and increases air moisture. Winter is usually mild here, mainly due to the high mountains in the north, which protect Crimea from cool continental winds.

Cape Tarhankut lies in the west part of Crimea and comprises a lowland area, with steppe grasses and herbs and patches of shrubs. Among the shrubs, hawthorn (Crataegus pojarcoviae L.) is common, with bushy elms (Ulmus sp.) and rose (Rosa sp.). Herbaceous flora is extremely rich in species, mainly due to the geographic expansion of species from the Mediterranean region, Central Asia, and Europe.

The aim of this paper is to compare the populations of oribatid mites and their communities from various steppe vegetation patches on cape Tarhankut in Crimea. 


\section{MATERIAL AND METHODS}

Samples of $500 \mathrm{~cm}^{3}$ each were taken on 15-20 July 2004, in 3 replicates, from 6 patches of steppe vegetation, dominated by esparto (Stipa sp.), other steppe grasses, Artemisia caucasica Willd., Sedum sp., mosses, or lichens. The mites were extracted in Tullgren funnels, preserved, and identified to species or genus level, including the juvenile stages. Nearly 13500 oribatid mites were extracted in total. Each oribatid species was characterized by the abundance $(A=$ mean number of individuals per sample) and dominance index $(D=\%$ of the total number of oribatid mites per sample). Oribatid mite communities in individual vegetation types were compared by mean density of all oribatid mites, number of species, and the Shannon index $H^{\prime}$ (ODum 1971). Names of oribatid species follow Subías (2004) and partly WeIGMANN (2006).

\section{RESULTS}

In the investigated habitats, oribatid mites were most abundant in patches of steppe grasses other than esparto, relatively abundant in patches of mosses and sedum, and the least abundant in patches of lichens (Table 1). The richest in species of oribatid mites were patches of sedum, relatively rich were patches of esparto, mosses and grasses, while the poorest in species were patches of lichens. Consequently the Shannon index for these mite communities was the highest in patches of mosses, and the lowest in patches of lichens.

Table 1. Characteristics of oribatid communities in Crimean steppe: mean density (individuals per mean sample, i.e. $\left.500 \mathrm{~cm}^{3}, n=3\right)$, number of species, and Shannon index of diversity $\left(H^{\prime}\right)$

\begin{tabular}{lcccccc}
\hline Characteristic & Esparto & Other grasses & Artemisia & Sedum & Mosses & Lichens \\
\hline & & & & & & \\
Mean density of Oribatida & 189.3 & 824.0 & 202.7 & 558.0 & 645.3 & 90.0 \\
Number of species & 35 & 32 & 20 & 40 & 35 & 19 \\
Shannon index $H^{\prime}$ & 2.50 & 2.09 & 2.07 & 2.00 & 2.82 & 1.89 \\
\hline
\end{tabular}

In patches of steppe vegetation, the most abundant and common was Tectocepheus velatus (Michael, 1880), which preferred patches of steppe grasses other than esparto, but was relatively abundant also in sedum patches (Table 2). Other relatively abundant species included Scutovertex sp. 1, Trhypochthonius tectorum (Berlese, 1896), and Liebstadia similis (Michael, 1888) in patches of sedum, Jacotella neonominata Subías, 2004, Oribatula sp. 2 and Ramusella fasciata (Paoli, 1908) in patches of mosses, and Scheloribates laevigatus (C. L. Koch, 1835) and Oribatula sp. 3 in patches of steppe grasses other than esparto. 
Table 2. Characteristics of oribatid species in Crimean steppe: abundance ( $A=$ individuals per mean sample, i.e. $\left.500 \mathrm{~cm}^{3}, n=3\right)$ and dominance index $(D=\%$ of the total number of oribatid mites in the mean sample). Species with maximum $A \leq 10$ are listed below the table

\begin{tabular}{|c|c|c|c|c|c|c|c|}
\hline Species & & Esparto & $\begin{array}{l}\text { Other } \\
\text { grasses }\end{array}$ & Artemisia & Sedum & Mosses & Lichens \\
\hline \multirow{2}{*}{ Arthrodamaeus sp. 1} & $A$ & 15.0 & 8.3 & 1.3 & 2.3 & 41.3 & 1.3 \\
\hline & $D$ & 7.9 & 1.0 & 0.6 & 0.4 & 6.4 & 1.4 \\
\hline \multirow{2}{*}{$\begin{array}{l}\text { Berniniella azerbeidjanica } \\
\text { (Kuliev, 1962) }\end{array}$} & $A$ & 0 & 13.3 & 0 & 0 & 0 & 0 \\
\hline & $D$ & 0 & 1.6 & 0 & 0 & 0 & 0 \\
\hline \multirow{2}{*}{$\begin{array}{l}\text { Cosmochthonius lanatus } \\
\text { (Michael, 1885) }\end{array}$} & $A$ & 0 & 0 & 0 & 0 & 38.7 & 0 \\
\hline & $D$ & 0 & 0 & 0 & 0 & 6.0 & 0 \\
\hline \multirow{2}{*}{$\begin{array}{l}\text { Eupelops acromios } \\
\text { (Hermann, 1804) }\end{array}$} & $A$ & 9.0 & 2.3 & 6.3 & 5.3 & 16.3 & 1.0 \\
\hline & $D$ & 4.7 & 0.2 & 3.0 & 0.9 & 2.5 & 1.1 \\
\hline \multirow{2}{*}{ Galumna sp. 1} & $A$ & 1.3 & 2.0 & 12.0 & 0 & 0 & 1.0 \\
\hline & $D$ & 0.5 & 0.2 & 5.9 & 0 & 0 & 1.1 \\
\hline \multirow{2}{*}{$\begin{array}{l}\text { Haplochthonius simplex } \\
\text { Willmann, } 1930\end{array}$} & $A$ & 3.3 & 0 & 2.3 & 0 & 16.3 & 0 \\
\hline & $D$ & 1.6 & 0 & 1.0 & 0 & 2.5 & 0 \\
\hline \multirow{2}{*}{$\begin{array}{l}\text { Jacotella neonominata } \\
\text { Subías, } 2004\end{array}$} & $A$ & 18.3 & 24.3 & 0 & 1.7 & 116.3 & 0 \\
\hline & $D$ & 9.5 & 2.9 & 0 & 0.2 & 18.0 & 0 \\
\hline \multirow{2}{*}{$\begin{array}{l}\text { Liebstadia similis } \\
\text { (Michael, 1888) }\end{array}$} & $A$ & 0 & 0 & 17.0 & 59.0 & 0 & 0 \\
\hline & $D$ & 0 & 0 & 8.4 & 10.6 & 0 & 0 \\
\hline \multirow{2}{*}{ Liebstadia sp. 1.} & $A$ & 0 & 4.3 & 0 & 1.3 & 11.3 & 0 \\
\hline & $D$ & 0 & 0.5 & 0 & 0.2 & 1.7 & 0 \\
\hline \multirow{2}{*}{$\begin{array}{l}\text { Lucoppia burrowsi } \\
\text { (Michael, 1890) }\end{array}$} & $A$ & 1.3 & 17.7 & 0 & 0 & 48.0 & 0 \\
\hline & $D$ & 0.5 & 2.1 & 0 & 0 & 7.4 & 0 \\
\hline \multirow{2}{*}{$\begin{array}{l}\text { Neoliodes theleproctus } \\
\text { (Hermann, 1804) }\end{array}$} & $A$ & 24.0 & 9.3 & 0 & 6.3 & 7.3 & 2.3 \\
\hline & $D$ & 12.6 & 1.1 & 0 & 1.1 & 1.1 & 2.2 \\
\hline \multirow[t]{2}{*}{ Oribatula sp. 1} & $A$ & 6.3 & 40.7 & 0 & 9.0 & 5.3 & 1.3 \\
\hline & $D$ & 3.2 & 4.9 & 0 & 1.6 & 0.8 & 1.4 \\
\hline \multirow{2}{*}{ Oribatula sp. 2} & $A$ & 0 & 0 & 0 & 0 & 96.0 & 0 \\
\hline & $D$ & 0 & 0 & 0 & 0 & 14.9 & 0 \\
\hline \multirow{2}{*}{ Oribatula sp. 3} & $A$ & 0 & 100.3 & 7.3 & 0 & 0 & 0 \\
\hline & $D$ & 0 & 12.1 & 3.5 & 0 & 0 & 0 \\
\hline \multirow{2}{*}{$\begin{array}{l}\text { Passalozetes hispanicus } \\
\text { Mihelčič, } 1953\end{array}$} & $A$ & 34.3 & 44,3 & 0 & 4.7 & 11.0 & 0 \\
\hline & $D$ & 17.9 & 5.3 & 0 & 0.8 & 1.7 & 0 \\
\hline \multirow{2}{*}{$\begin{array}{l}\text { Peloribates pilosus } \\
\text { Hammer, } 1952\end{array}$} & $A$ & 0 & 1.3 & 32.7 & 0 & 0 & 0 \\
\hline & $D$ & 0 & 0.1 & 15.8 & 0 & 0 & 0 \\
\hline \multirow{2}{*}{$\begin{array}{l}\text { Ramusella fasciata } \\
\text { (Paoli, 1908) }\end{array}$} & $A$ & 1.0 & 1.0 & 0 & 0 & 85.7 & 0 \\
\hline & $D$ & 0.5 & 0.1 & 0 & 0 & 13.2 & 0 \\
\hline \multirow{2}{*}{$\begin{array}{l}\text { Scheloribates laevigatus } \\
\text { (C. L. Koch, 1835) }\end{array}$} & $A$ & 4.0 & 108.3 & 8.3 & 22.3 & 19.3 & 0 \\
\hline & $D$ & 2.1 & 13.1 & 3.9 & 3.9 & 3.0 & 0 \\
\hline \multirow{2}{*}{$\begin{array}{l}\text { Sphaerochthonius } \\
\text { splendidus (Berlese, 1904) }\end{array}$} & $A$ & 2.3 & 23.7 & 1.7 & 0 & 15.0 & 0 \\
\hline & $D$ & 1.1 & 2.8 & 0.8 & 0 & 2.3 & 0 \\
\hline \multirow{2}{*}{ Scutovertex sp. 1} & $A$ & 4.3 & 35.7 & 7.3 & 180.7 & 30.3 & 0 \\
\hline & $D$ & 2.1 & 4.3 & 3.5 & 32.4 & 4.7 & 0 \\
\hline \multirow{2}{*}{$\begin{array}{l}\text { Tectocepheus velatus } \\
\text { (Michael, 1880) }\end{array}$} & $A$ & 47.3 & 357.0 & 88.3 & 147.3 & 41.0 & 30.3 \\
\hline & $D$ & 24.7 & 43.3 & 43.4 & 26.3 & 6.4 & 32.6 \\
\hline \multirow{2}{*}{$\begin{array}{l}\text { Trhypochthonius tectorum } \\
\text { (Berlese, 1896) }\end{array}$} & $A$ & 1.3 & 2.3 & 5.3 & 85.0 & 1.3 & 45.3 \\
\hline & $D$ & 0.5 & 0.2 & 2.5 & 15.2 & 0.2 & 38.4 \\
\hline
\end{tabular}


Less frequent oribatid species found in studied vegetation types:

Esparto: Achipteria sp. 1; Aphelacarus acarinus (Berlese, 1910); Ceratozetes sp.; Galumna tarsipennata (Oudemans, 1913); Malaconothrus monodactylus (Michael, 1888); Metabelba pulverulenta (C. L. Koch, 1839); Micreremus brevipes (Michael, 1888); Microppia minus (Paoli, 1908); Microtritia sp.; Oppiella nova (Oudemans, 1902); Oribatula sp. 4; Peloptulus phaenotus (C. L. Koch, 1844); Phthiracarus sp. 1; Phyllozetes emmae (Berlese, 1910); Protoribates obtusus (Mihelčič, 1956); Punctoribates punctum (C. L. Koch, 1839); Quadroppia quadricarinata (Michael, 1885); Ramusella clavipectinata (Michael, 1885); Suctobelba sp.; Trichoribates incisellus (Kramer, 1897).

Other grasses: Brachychthonius sp.; Carabodes sp.1; Ceratozetes sp.; Liacarus coracinus (C. L. Koch, 1841); Licneremaeus licnophorus (Michael, 1882); Metabelba pulverulenta; Microppia minus; Oppiella nova; Oribatula sp. 5; Peloptulus phaenotus; Phyllozetes emmae; Suctobelba sp.; Trichoribates incisellus; T. trimaculatus (C. L. Koch, 1835).

Artemisia: Brachychthonius sp.; Camisia horrida (Hermann, 1804); Galumna tarsipennata; Metabelba pulverulenta; Microppia minus; Oppiella nova; Phyllozetes emmae; Trichoribates incisellus; T. trimaculatus.

Sedum: Achipteria sp. 1; Aphelacarus acarinus; Berniniella sp.; Bipassalozetes sp.; Brachychthonius sp.; Camisia horrida; Ceratozetes sp.; Chamobates sp.1; Conchogneta tragardii (Forsslund, 1947); Liacarus coracinus; Galumna lanceata (Oudemans, 1900); G. tarsipennata; Hypochthonius rufulus (C. L. Koch, 1835); Licnobelba sp. 1; Nanhermannia comitalis Berlese, 1916; Nothrus anauniensis Canestrini et Fanzago, 1876; Oppiella nova; Oribatula tibialis (Nicolet, 1855); Oribatula sp. 5; Peloptulus phaenotus; Phthiracarus sp. 1; Platynothrus peltifer (C. L. Koch, 1839); Protoribates sp. 1; Ramusella clavipectinata; Scheloribates barbatulus (Mihelčič, 1956); Suctobelba sp.; Trichoribates incisellus; T. trimaculatus.

Mosses: Achipteria sp. 1; Austrocarabodes sp.1; Brachychthonius sp.; Ceratozetes sp.; Chamobates sp. 1; Dissorhina ornata (Oudemans, 1900); Dorycranosus curtipilis Willmann 1935; Galumna tarsipennata; Eueremaeus sp.1; Licnodamaeus sp. 1; Oppiella nova; Oribatula sp. 4 and 5; Peloptulus phaenotus; Protoribates obtusus; Punctoribates punctum; Suctobelba sp.; Trichoribates trimaculatus.

Lichens: Achipteria sp. 1; Brachychthonius sp.; Ceratozetes sp.; Galumna tarsipennata; Malaconothrus monodactylus; Oribatula sp. 4 and 5; Peloptulus phaenotus; Protoribates sp.1; Ramusella clavipectinata; Trichoribates incisellus; T. trimaculatus.

Among the oribatid mites, adults usually dominated, except for lichens, where juvenile stages were more abundant, mainly due to Trhypochthonius tectorum, as its juveniles were 6.5 times more abundant than the adults (Table 3 ). The age structure of oribatid mites greatly depended on vegetation type.

\section{DISCUSSION}

In the investigated patches of vegetation in Crimean habitats, the density and species number of oribatid mites were highly differentiated and depended on vegetation type. In Mediterranean climate, the main limiting factors for oribatid mites are high temperature and low precipitation (AтTENBorough et al. 1989), so the kind of plant cover is important for mites. For example, patches of dense steppe grasses (other than esparto) form a turf, which stores more water, protects the soil against evaporation, and provides the mites with food, which resulted in the highest density of mites. The patches of sedum and mosses are probably also able to store more wa- 
Table 3. Age structure of some oribatid species in Crimean steppe habitats: mean density of individuals per $500 \mathrm{~cm}^{3}(\mathrm{n}=3)$ of juvenile stages (Juv) and adults (Ad)

\begin{tabular}{llrrr}
\hline \multirow{2}{*}{ Species } & Habitat & Juv & \multicolumn{1}{l}{ Ad } & Total \\
\hline Arthrodamaeus sp. 1 & Mosses & 12.0 & 29.3 & 41.3 \\
\hline \multirow{2}{*}{ Neoliodes theleproctus } & Esparto & 8.3 & 15.7 & 24.0 \\
& Other grasses & 4.3 & 5.0 & 9.3 \\
\hline Oribatula sp. 2 & Mosses & 36.7 & 59.3 & 96.0 \\
\hline \multirow{2}{*}{ Scheloribates laevigatus } & Other grasses & 81.3 & 27.0 & 108.3 \\
& Mosses & 6.3 & 13.0 & 19.3 \\
\hline \multirow{2}{*}{ Scutovertex sp. 1 } & Sedum & 77.0 & 103.7 & 180.7 \\
& Other grasses & 9.3 & 26.4 & 35.7 \\
\hline \multirow{2}{*}{ Tectocepheus velatus } & Other grasses & 25.7 & 331.3 & 357.0 \\
& Sedum & 57.0 & 90.3 & 147.3 \\
& Mosses & 30.7 & 10.3 & 41.0 \\
Trhypochthonius tectorum & Lichens & 16.3 & 14.0 & 30.3 \\
\hline
\end{tabular}

ter, so the density of mites in them was distinctly higher than in patches of esparto, artemisia, and lichens.

Among oribatid mites in Crimean steppe, the highest density was achieved by Tectocepheus velatus, which is cosmopolitan (NüBEL-REIDELBACH 1994, Subias 2004), and can be abundant in both extremely dry and wet habitats (RAJSKI 1968). Relatively abundant were Scutovertex sp. 1, Jacotella neonominata, Trhypochthonius tectorum and Liebstadia similis, which prefer dry habitats, while Scheloribates laevigatus is typical for meadows (RAJSKi 1968, PÉREZ-ÍÑIGO 1993). Generally, in patches of steppe plants, 1-2 species achieved a high density and dominance index, which indicate in the light of THIENEMANN's (1939) principles rather low soil fertility, probably because of low precipitation. For example, in patches of artemisia and steppe grasses other than esparto, Tectocepheus velatus comprised $43.3 \%$ of all oribatid mites, while in patches of lichens this species and Trhypochthonius tectorum comprised jointly $71 \%$ of all oribatid mites. However, the oribatid communities were richer in individuals and species than those from the south part of Andalusia and Rhodes Island (SuBíAS at al. 1985, Seniczak \& Seniczak 2006, Seniczak \& Seniczak 2009), probably due to the fresh sea breeze, which slightly lowers the temperature and increases air moisture in the hot season, and also due to expansion of mites from Central Asia and Europe. Probably that is also why the Shannon index of oribatid mite communities of Crimean steppe was higher than in patches of vegetation in south Andalusia (SENICZAK \& SENICZAK 2009). 
Adults usually dominated in mite communities, but the age structure of species depended greatly on vegetation type, which was conspicuous in Tectocepheus velatus. In patches of steppe grasses other than esparto this species was abundant, but poor in juveniles, while in patches of mosses it was not abundant, but juveniles dominated. Based on the list of oribatid species from the Caucasus and Crimea (KARPPINEN et. al. 1987), Jacotella neonominata Subías, 2004 [= Jacotella ornata (Pérez-Íñigo, 1972)] and Lucoppia burrowsi (Michael, 1890) are new to Crimea.

\section{CONCLUSIONS}

1. The summer oribatid mite communities of investigated patches in Crimean steppe were rather abundant and rich in species, which was probably caused by the fresh sea breeze and geographic expansion of species from the Mediterranean region, Central Asia and Europe.

2. Oribatid mites achieved the highest density in patches of steppe grasses other than esparto, while most species occurred in sedum patches.

3. Among oribatid mites, the highest density was achieved by Tectocepheus velatus, especially in patches of steppe grasses other than esparto, and relatively abundant were Scutovertex sp. 1, Jacotella neonominata and Scheloribates laevigatus.

4. In populations of oribatid species the adults usually dominated, but age structure greatly depended on vegetation type.

\section{REFERENCES}

Attenborough D., Whitfield P., Moore P. D., Cox B. 1989. The atlas of the living world. Marshal Edition Ltd.

Karppinen E., Krivoluckis D. A., Tarba Z. M., Shtanchaeva U. Ya, Godreeva E. W. 1987. List of oribatid mites (Acarina, Oribatei) from northern Palaearctic region. IV. Caucasus and Crimea. An. Ent. Fen. 53: 119-137.

NüBel-Reidelbach E. 1994. Taxonomie und Systematik der Gattung Tectocepheus Berlese, 1895 [Taxonomy and systematic of genus Tectocepheus Berlese, 1895]. Andrias. 12: 3-94.

Odum E. P. 1971. Fundaments of ecology. W. B. Saunders Co., Georgia.

Pérez-Í̃̃Igo C. 1993. Acari, Oribatei, Poronota. In: Fauna Iberica (RAmos A. et al., Eds), vol. 3: 1-320. Museo de Ciencias Naturales, Madrid.

RAJSKI A. 1968. Autecological-zoogeographical analysis of moss mites (Acari, Oribatei) on the basis of fauna in the Poznan environs. Part. II. Fragm. Faun. 14: 277-403.

Seniczak S., Seniczak A. 2006. The oribatid mites (Acari) of some habitats of Rhodes Island (Greece). Biological Lett. 43: 215-219.

SenicZak S., Seniczak A. 2009. The oribatid mites (Acari, Oribatida) of some habitats of south part of Andalusia (Spain). Biological Lett. (in press).

SuBíAs L. S. 2004. Listado sistemático, sinonímico y biogeográfico de los Ácaros Oribátidos (Acariformes, Oribatida) del mundo (1758-2002) [Systematic, synonymic and biogeographical check - list of the world's oribatid mites (Acariformes, Oribatida) (1758-2002)]. Graellsia. 60: $3-305$.

Subías L. S., Ruiz E., Minguez M. E. 1985. Aportación al conocimiento de las comunidades de Oribatidos (Acari) del erial mediterráneo [Contribution to the knowledge of the communities 
of Oribatida (Acari) from the Mediterranean heath]. Actas do II Congresso Ibérico de Ent. 1: 389-398.

Thienemann A. 1939. Grundzüge einer allgemainen Oecologie [Principle of general ecology]. Arch. Hydrobiol. 35: 267-285.

Weigmann G. 2006. Hornmilben (Oribatida) [Oribatid mites (Oribatida)]. In: Die Tierwelt Deutschland und der angrenzenden Meeresteile (DAHL F. Ed), 76. Teil, pp. 1-520, Goecke \& Evers, Keltern. 